\title{
Assessing Indonesian Youth Acceptance of Corruption: Applying the Stimulus-Organism-Response Framework
}

\author{
Sabrina O. Sihombing \\ Hendra Achmadi \\ Faculty of Economics and Business, \\ Universitas Pelita Harapan, MH Thamrin Boulevard 1100, \\ Klp. Dua, Kec. Klp. Dua, Kota Tangerang, \\ Banten 15811, Indonesia
}

DOI: https://doi.org/10.36941/ajis-2022-0047

Abstract

Corruption is one of the old problems facing the Indonesian government to date. The Covid-19 pandemic has not reduced corrupt behaviour in Indonesia. In fact, state officials in Indonesia were arrested for corruption in providing government social assistance to communities affected by this pandemic. Based on this phenomenon, this study aims to predict corruption acceptance behaviour using a stimulus-organismresponse framework. The research focuses on youth because youth are future adults who will be active in business, politics, community activities, and others. A total of 246 youth was respondents in this study. Judgmental sampling was applied in this study and questionnaires were distributed online. The data was then analysed using structural equation modelling. The results of the analysis show that 4 of the 8 research hypotheses are supported. The four hypotheses supported are that anti-social media exposure has a negative relationship with personal values of materialism and materialism has a positive relationship with acceptance of corruption. The results of the analysis also show that pro social media exposure has a positive relationship with religious involvement. Furthermore, religious involvement has a negative relationship with acceptance of corruption. Limitations and suggestions for further research are also presented in this paper.

Keywords: stimulus-organism-response, corruption, youth, Indonesia

\section{Introduction}

Entering the end of 2020, to be precise 6 December 2020, the Indonesian people were shocked by the arrest of Social Minister Juliari Batubara by the Corruption Eradication Commission (KPK). Juliari Batubara was arrested in connection with the Covid-19 social assistance corruption case. Juliari Batubara was arrested for a bribery case worth Rp. 17 billion from the appointment of a groceries procurement partner for residents affected by Covid-19. The allegation of corruption in social assistance then became the public spotlight because it was considered ironic during a difficult situation in society facing the Covid-19 pandemic (CNN Indonesia, 2020). Another bribery case related to emergency response goods for the Covid-19 pandemic made the Regent of Bandung Barat (Aa Umbara) has arrested on 1 April 2021 (Kamil, 2021). 
In November 2020, the Minister of Maritime Affairs and Fisheries Edhy Prabowo was arrested for accepting bribes for permits for ponds, businesses and / or management of fisheries or other similar marine commodities. The Indonesian people were also shocked again when the Governor of South Sulawesi Nurdin Abdullah, on February 26, 2021, was arrested and named a suspect in the alleged bribery case for infrastructure projects in the South Sulawesi Provincial Government. In fact, Nurdin Abdullah has won the Bung Hatta Anti-Corruption Award in 2017 because he is listed as a government official who is free from corruption practices (Tempo.co, 2021).

The Covid-19 pandemic has apparently not reduced government officials' desire for corruption, as stated by Delia Ferreira Rubio, chairman of the board of directors of Transparency International in the launch of the Corruption Perception Index 2020 on Thursday, January 28 that "Covid-19 is not only a health crisis and economy. But also, the crisis of corruption and democracy." Indicators of corruption in Indonesia are getting worse. This can be seen from the decline in Indonesia's corruption perception index (CPI) in 2020 issued by Transparency International (TI). Indonesia's CPI in 2020 is at a score of $37 / 100$ and is ranked 102 out of 180 countries surveyed. This score is down 3 points from last year's 2019 which was at a score of 40/100 (Transparency International Indonesia, 2021). TI uses a scale of o-10o to measure GPA. A score of zero indicates a country is highly corrupt. On the other hand, a score of 100 indicates the country is very clean from corruption. With the current score, it means that the problem of corruption in Indonesia is still worrying.

Corruption is one of the old problems facing the Indonesian government to date. Government efforts to reduce corruption, for example by increasing employee salaries, procedures for purchasing and procuring goods through electronic procurement, and various other means have not yielded significant results in reducing corruption. Appendix 1 shows a list of the names of the government officials and their positions and the corruption cases that they are being charged.

The problem of corruption is not only a problem in practice but also a problem in theory. Often agency theory (i.e., principal-agent problems) provides a theoretical basis for corruption research (e.g., Zimelis, 2020; Simmonds et al., 2016; Jansics, 2014). However, this theory would then limit the scope of research to the analysis of individuals in organization / management. To fulfil the research gap, this study uses a stimulus-organism-response theory framework to predict youth corruption acceptability. Furthermore, to the best of our knowledge, there is no research applying the SOR theory as the foundation to analyse the relationship between the stimulus factors, organism factors and the response factor. Specifically, media exposure is a stimulus that then affects the organism which is specifically represented by personal values (materialism), perceptions of corruption, integrity, and involvement in religion. Then the response from the individual is represented by acceptance of corruption. This study used a youth sample. Youth will become actors in business, politics, and many other fields. Not only that, the first President of the Republic of Indonesia, Soekarno, once stated, "Give me 1000 parents, I will definitely erase Semeru from its roots. Give me 10 youths, I will shake the world" (emphasis added). This quote shows the important role of youth for the nation, especially the Indonesian nation. An understanding of the perspective of young people about corruption will be able to predict corrupt behaviour in the future when they have become business and political actors in society. Therefore, this study aims to fill existing research gaps and aims to predict youth corruption acceptance through a stimulus-organism-response framework.

\section{Literature Review}

\subsection{Corruption: the dark side of management}

One definition of corruption that is often used is the abused of entrusted power for private gain (e.g., Abashidze \& Gvalia, 2020; Zimelis, 2020). The dark side is not something that is studied frequently in many fields, including management. The positives of many fields are widely discussed and researched. However, the dark side also needs to be considered to increase knowledge. Fortunately, the dark side is not a 'taboo' topic, but it can sometimes be considered "the elephant in the room". 
The dark side has been discussed and integrated in many topics such as consumer behaviour (e.g., Ebrahimi et al., 2020; Tuhin, 2019), organizational behaviour (e.g., Zhang et al., 2020; Linstead et al., 2014), leadership (e.g., Zhang et al., 2020), and others.

Corruption is the "elephant in the room" in the context of management and organization (Locatelli et al., 2017). People in the organization know something is wrong (that is, corruption) but are mostly silent until top management finds out themselves or the organization's authorities find out. This could also be because corruption is considered endemic (Locatelli et al., 2017). As stated by Napoleon Bonaparte that "The world suffers a lot. Not because of the violence of bad people but because the silence of good people". As the elephant in the room, if corruption is ignored, it will damage people, management, and the organization. Neglect can be caused because corruption does not have an immediate effect on everyone in the company. Thus, it is possible that some think it (corruption) is not my business. Or there are those who think that corrupt practices are commonplace (if they are not caught). In the Indonesian context, there is a view that if someone caught in the act of corruption is often considered "unlucky" and not because they must be arrested (Fadhil, 2018).

\subsection{Stimulus-Organism-Response framework}

Individual behaviour can be understood by using a stimulus-organism-response (S-O-R) framework. This framework is the extension of the simple form of understanding people behaviour through Input-Output (I-O) process (Jacoby, 2002). Through the S-O-R framework, it shows that individuals receive stimuli which are then processed internally before the individual acts. A stimulus is anything that can be accepted by the five senses of man. The stimulus can be in the form of what the individual can see, hear, feel, hold, and so on. Then, the organism is the individual who receives the stimulus. Based on Jacoby (2020), stimulus factors can be categorized as things that include all external stimuli such as products, brands, logos, ads, packages, prices, stores and store environments, word-of-mouth communications, newspapers, television, and other external factors. This research applied media exposure as a stimulus factor in the research model.

As the extended version of I-O process, the S-O-R framework shows that individuals are not black boxes whose internal processes are not understood. There are many factors in the individual as a factor which then processes the stimulus through cognitively, affective, and conative. The organisms can be categorized as knowledge, beliefs, attitudes, predispositions, intentions, values, personality, feelings, images, expectations, and so forth (Jacoby, 2002). This research applied personal value of materialism, perceived corruption, integrity, and religious involvement as organism variables in the research model. The process in the individual's internal then drives an action (response). This research applied corruption acceptability as a representation of individual response. All research variables are explained as follows.

\subsection{Media exposure}

Media exposure is the exposure of media content from traditional media and its affiliates on the Internet which can be accessed through the Web, mobile applications, and others ( $\mathrm{Wu} \mathrm{\&} \mathrm{Li,} \mathrm{2017).}$ Exposure is an activity to hear, see and read mass media messages or experience and attention to these messages that can occur in individuals or groups. Specifically, when someone listens to radio broadcasts, watches television, or reads newspapers, he is dealing with or exposed to the mass media, where the media messages are directly or indirectly influencing him. Exposure is an activity to hear, see and read mass media messages or experience and attention to these messages that can occur in individuals or groups. When people have listened to radio broadcasts, watched television, or read newspapers, or browsing the Internet, whether on purpose or just coincidence, they have exposure to the content media which may contain positive or negative content. Media is a social force that affect people behaviour and movement (Tugtekin \& Koc, 2020; Kepplinger, 2017; Skoric et al., 2016). Media exposure may lead to psychological stress (Stainback et al., 2020). Specifically, research shows that negative or 
antisocial media exposure leads to people negative behaviour. These negative media exposures such as porn and drinking alcohol exposures lead to free sexual dan drinking alcohol intention respectively (e.g., Geusens et al., 2020; Abdullahi \& Abdulquadri, 2018; Angwarmase et al., 2016).

\subsection{Materialism}

Many studies have shown that personal values lead to people behaviour. On of core values of many people especially in develop countries is materialism. Materialism refers to the importance of having many possessions for having a well-being (Burroughs \& Rindfleisch, 2002). The expression of "He who dies with the most toys win" is easily find especially in a society where materialism is promoted constantly. For people who value materialism believe that acquiring possessions is important (Sousa et al., 2019).

Materialism values are often accused of being a factor in causing corruption. This is because materialism emphasizes the importance of life if it has matter. Ownership of large houses, luxury cars, brand name goods, etc. often leads people to look for quick ways to earn money and leads them to corrupt. Still related to materialism, often individuals who want service, luxury and respect must pay for what they want with money. This is what often encourages someone to commit acts of corruption. Several studies show the positive significant relationship between materialism and intention corruption acceptability (Liang et al., 2016; Makhlouf, 2016).

\subsection{Corruption perception}

Perception is a cognitive concept (Leister \& MacLachlan, 1975) which explains how individuals in the process of selecting, arranging, and interpreting sensations into a meaningful whole (Hanna \& Wozniak, 2001). Perception is one of the main factors in human internal that affects human behaviour (Mothersbaugh. \& Hawkins, 2016; Schiffman \& Wisenblit, 2015). This is because perception is our lens in seeing reality. Our perceptions process and interpret the stimuli we receive every day subjectively. Thus, what we see and interpret on an object can then be different from what others see and interpret (Schiffman \& Wisenblit, 2015; Hanna \& Wozniak, 2001). It can be said, everyone has their own unique version of seeing reality.

Corruption is also often associated with people's perceptions of what corruption is. Tverdova (2011) shows heterogeneity in public perceptions of corruption. One measure of corruption is the use of perception. For example, the Corruption Perception Index (CPI) is an index that explains how corrupt a country is. CPI is also the most widely used indicator of corruption worldwide. Corruption research in the management sector also uses corruption as a perception (e.g., Merhi \& Ahluwalia, 2018; Makhlouf, 2016; Tverdova, 2011). The literature also shows that there are 2 conflicting perspectives regarding corruption in management (Cuervo-Cazurra, 2016). The two views are (1) a negative view that views corruption as a "sand in the wheels of commerce" (e.g., Hoinaru et al., 2020; Nur-tegin \& Jakee, 2020; Hanoteau \& Vial, 2014) and (2) a positive view that views corruption as a "grease in the wheels of commerce" (e.g., Heo et al., 2020). Specifically, corruption as "sand" indicates that corruption affects the ability of companies to operate efficiently, and a positive view of corruption as "fat" indicates that corruption allows companies to operate better. However, the literature shows that the view of corruption as "fat" does not have as much empirical support as the view of corruption as "sand" (Dimant \& Tosato, 2017). This research applied perceived corruption refers to an individual perception toward their environment which might be infected by any corrupt behaviours or involved in any corruption activities including bribery, embezzlement, extortion, and other corruption activities (Bai et al., 2014).

\subsection{Integrity}

The literature in management shows corruption and integrity are closely related (Dobel, 2017). Specifically, corruption is caused by a lack of integrity (Dobel, 2017; Pyman, 2008). There are many 
studies on integrity in management (e.g., Thomas, 2019; Prottas \& Nummelin, 2018). The results show that integrity is the main aspect of work behaviour (Moorman \& Grover, 2009), as a predictor of work performance (Ones et al., 1993), and show the quality of leadership in organizations (Karthikevan, 2017). Not only that, but the literature also shows that individuals with integrity can create organizations, build culture, adhere to standards, and achieve accountability (Dobel, 2017).

Integrity is a complex construct (Barnard et al., 2008). Furthermore, it is not easy to reduce this construct to a simple definition (Carbajal \& Chavez, 2007). People will show integrity as a good character (Audi \& Murphy, 2006) which represents the quality of a person's character (Carbajal \& Chavez, 2007). People whose integrity is as synonymous with fairness, fairness, consistency, and fulfilment of promises (Colquitt et al., 2007). Furthermore, Colquitt et al. that integrity can be defined as the extent to which an individual does not comply with moral and ethical principles. Huberts (2018) states that the foundation of integrity is about quality behaviour that refers to moral values and norms. In the context of management, integrity which can reduce negative and external forces, for example human greed, to groups that exploit the organization can damage the organization (Dobel, 2017).

\subsection{Religious involvement}

Religious involvement is the level of participation in religious beliefs and practices and takes part in worship activities, groups, committees, and worship-related organizations (e.g., Abbas et al., 2020; Mueller et al., 2001). Religious involvement is concerned with means and methods (for example, prescribed rituals or behaviours) in the sacred search for they believe in and who receive validation and support from within religion (Hill et al., 2000). Religious involvement is not the same as spirituality (Mueller et al., 2001). Spirituality is a broader concept than religion. Specifically, spirituality is primarily a dynamic, personal, and experiential process. Some people who regard themselves as spiritual do not endorse a formal religion.

Religion is one of the factors that influence and give meaning to human values and behaviour in their daily lives, including in their work in organizations or companies. The results of the study have shown a relationship between religious and positive things such as job involvement (Golmohammadian et al., 2014; Knotts, 2000). Furthermore, religious involvement is an important aspect of human life, and it usually has a positive association with good mental health and prosocial behaviour (e.g., Farhanfar et al., 2015; McKenzie et al., 2015; French et al., 2008).

\subsection{Corruption acceptability}

Corruption acceptability refers to individual attitudes towards corruption to achieve goals by bribing public officials in various situations (Tatarko \& Mironova, 2016). Corruption acceptability is an individual's response to corrupt behaviour that occurs in his environment. This is caused by many factors, both internal and external factors of the individual. In this study, corruption acceptability is a response from internal individuals which includes personal value (materialism), corruption perception, integrity, and religious involvement.

\subsection{Relationship between variables}

Media exposure is one way of promoting materialism to young people (Behal \& Soni, 2018). Exposure to well-known products and various brands means that these products and brands are used by many people then give influence on young people to prioritize themselves to own these well-known products and brands (e.g., Neve \& Trivedi, 2020; Pinto et al., 2017; Masood et al., 2016). Media exposure can be in the form of positive (pro-social) and negative (anti-social) content. Anti-social media exposure with content such as aggressive behavior, sex, and other matters related to materialism in a negative way. Specifically, more exposure to crime will affect the individual's concern about owning expensive branded goods. However, the pleasure of owning expensive items 
requires a lot of money. Therefore, the desire to own many expensive items can encourage people to accept corrupt behaviour (e.g., Aliyu et al., 2018; Liang et al., 2016; Makhlouf, 2016). Based on this explanation, the following research hypotheses can be presented as follows:

$\mathrm{H}_{1}$ : There is a negative relationship between anti-social media exposure and materialism.

$\mathrm{H} 2$ : There is a positive relationship between materialism and corruption acceptability.

Media exposure also affects people's perceptions of corruption. Exposure to crime, scandals, corruption, and other things affects a person's perception of corruption that corruption is a real thing and is a phenomenon of everyday life. Studies show that media exposure affects perception (e.g., Huang, 2020; Li, 2018; Jones, 2017; Rizzica \& Tonello, 2015). These perceptions then influence the individual's behaviour (e.g., Arshad et al., 2015; Wee et al., 2014; Ferguson \& Bargh, 2004). Thus, the following research hypothesis can be conveyed:

$\mathrm{H}_{3}$ : There is a positive relationship between anti-social media exposure and corruption perception.

$\mathrm{H}_{4}$ : There is a positive relationship between corruption perception and corruption acceptability.

The S-O-R framework shows that a stimulus affects the organism and then gives its reaction in the form of behaviour. Positive (pro-social) media exposure is believed to support the integrity of individuals in their life. The integrity of this individual will then prevent the individual from accepting corruptive behaviour (e.g., Putri \& Nihayah, 2017; Heissner, 2015). Thus, the research hypothesis is as follows:

$\mathrm{H}_{5}$ : There is a positive relationship between pro-social media exposure and integrity.

H6: There is a negative relationship between integrity and corruption acceptability.

Pro-social media exposure is believed to support one's involvement in one's religion (e.g., Syah, 2020; Hatta, 2018). Furthermore, studies show the influence of religion on individual behaviour (e.g., Salvatore \& Rubin, 2018; Ameri et al., 2017). Positive media exposure will then encourage the person's involvement in their religion. The more individuals are involved in their religion, the more they will prevent the individual from accepting corruptive behaviour. Thus, the research hypothesis is as follows:

$\mathrm{H}_{7}$ : There is a positive relationship between pro-social media exposure and religious involvement.

H8: There is a positive relationship between religious involvement and corruption acceptability.

\subsection{Research model}

The research model was developed based on a stimulus-organism-response framework to predict the acceptability of corruption. Media exposure represents stimulus factor and organisms are represented by materialism, corruption perception, integrity, and religious involvement. The response side is the acceptability of corruption. The research hypotheses are as follows.

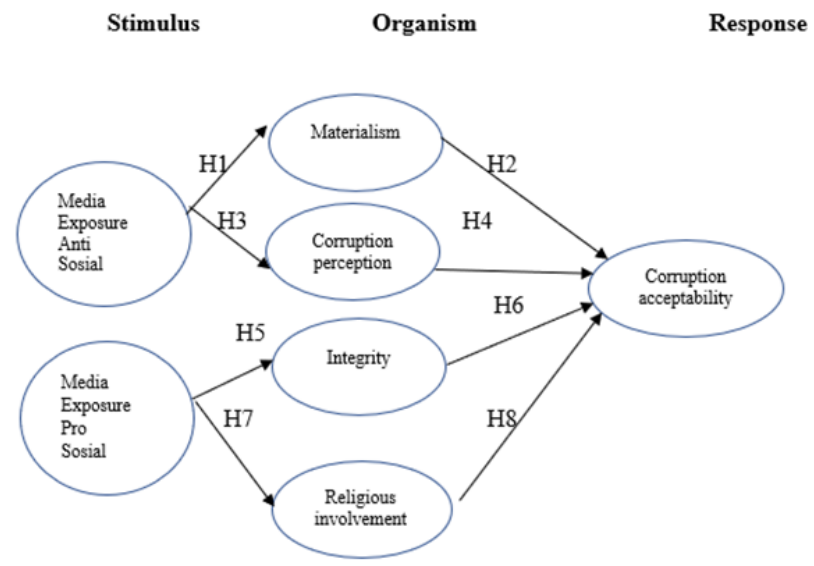

Figure 1: The Proposed Research Model 


\section{Research Method}

The quantitative research paradigm was the basis for this research. Specifically, this study was a descriptive and cross-sectional study where primary research data were collected through a survey. Judgmental sampling was used in this study. Specifically, the respondents used in this study were youth aged between 15 and 24 years based on WHO criteria. All research indicators are based on previous research. Items for anti and pro social media exposure were adopted from den Hamer et al. (2017). The materialism research indicators were adopted from Richins (2004) and the corruption perception indicators based on Saithibvongsa and JinKyo (2019). Furthermore, integrity items were based on Graham and Vicheth (2015) and indicators of religious involvement were adopted from Roth et al. (2012). Finally, the corruption acceptability indicators were based on Tatarko and Mironova (2016). Research indicators are available in Appendix 2. Likert scale 5-points were applied for all research items.

The sample size of this study was set to 200 respondents who were collected through an online questionnaire. This sample size was appropriate according to the use of structural equation modelling data analysis (e.g., Civelek, 2018; Bowen \& Guo, 2012; Kline, 2005). Furthermore, Hair et al. (2019) provides advice on sample size regarding the use of SEM. The suggestion is that the minimum sample size is at least 150 with a model that has seven constructs or less, with at least modest communality (0.5), and no under identified construct.

The goodness of the data was measured by applying reliability and validity tests. Structural equation modelling (i.e., CB-SEM) was applied for data analysis in this research as SEM can estimate models that contain one or more intervening variables in a single analysis procedure. In other words, SEM can assess one or more variables that serve as both independent and dependent variables simultaneously (Bowen \& Guo, 2012). This study applied multiple indices suggested by Hair et al. (2019) to assess the fit or not of a model, namely by applying $\chi^{2}$ value and degrees of freedom, the CFI, and the RMSEA, which provide sufficient information to evaluate a model. Specifically, RMSEA represents badness of fit (higher values mean relatively worse fit), whereas the others represent goodness of fit (higher values represent relatively better fit).

\section{Results and Discussion}

A total of 246 questionnaires can be processed and analysed in this study. The respondents of this research were teenagers. More than half $(56.5 \%)$ are female respondents. Before the data is processed for hypothesis testing, it is first carried out to test the correctness of the data through reliability and validity.

Table 1: Reliability and validity tests

\begin{tabular}{|c|c|c|c|c|c|}
\hline Construct & Item & Corrected item-total correlation & Crombach's Alpha & Contruct Reliability & AVE \\
\hline \multirow{3}{*}{ MEAS } & MEAS1 & 0.555 & \multirow{3}{*}{0.751} & \multirow{3}{*}{0.760} & \multirow{3}{*}{0.517} \\
\hline & MEAS2 & 0.650 & & & \\
\hline & $\mathrm{MEAS}_{3}$ & 0.539 & & & \\
\hline \multirow{3}{*}{ MEPS } & MEPS1 & 0.549 & \multirow{3}{*}{0.749} & \multirow{3}{*}{0.753} & \multirow{3}{*}{0.506} \\
\hline & MEPS2 & 0.631 & & & \\
\hline & $\mathrm{MEPS}_{3}$ & 0.552 & & & \\
\hline \multirow{3}{*}{ MAT } & MAT1 & 0.752 & \multirow{3}{*}{0.878} & \multirow{3}{*}{0.885} & \multirow{3}{*}{0.719} \\
\hline & MAT2 & 0.797 & & & \\
\hline & $\mathrm{MAT}_{3}$ & 0.767 & & & \\
\hline \multirow{4}{*}{ CPER } & CPER1 & 0.774 & \multirow{4}{*}{0.921} & \multirow{4}{*}{0.922} & \multirow{4}{*}{0.746} \\
\hline & CPER2 & 0.856 & & & \\
\hline & $\mathrm{CPER}_{3}$ & 0.835 & & & \\
\hline & CPER4 & 0.805 & & & \\
\hline
\end{tabular}




\begin{tabular}{|c|c|c|c|c|c|}
\hline \multirow{3}{*}{ INTG } & INTG1 & 0.659 & \multirow{3}{*}{0.788} & \multirow{3}{*}{0.795} & \multirow{3}{*}{0.566} \\
\hline & INTG2 & 0.657 & & & \\
\hline & INTG $_{3}$ & 0.575 & & & \\
\hline \multirow{4}{*}{ RINV } & RINV$_{1}$ & 0.667 & \multirow{4}{*}{0.834} & \multirow{4}{*}{0.842} & \multirow{4}{*}{0.575} \\
\hline & RINV$_{2}$ & 0.729 & & & \\
\hline & $\mathrm{RINV}_{3}$ & 0.712 & & & \\
\hline & RINV $_{4}$ & 0.567 & & & \\
\hline \multirow{4}{*}{ CACC } & $\mathrm{CACC}_{1}$ & 0.716 & \multirow{4}{*}{0.852} & \multirow{4}{*}{0.855} & \multirow{4}{*}{0.597} \\
\hline & $\mathrm{CACC}_{2}$ & 0.737 & & & \\
\hline & $\mathrm{CACC}_{3}$ & 0.693 & & & \\
\hline & $\mathrm{CACC}_{4}$ & 0.637 & & & \\
\hline
\end{tabular}

MEAS: Media Exposure Anti-Social

MEPS: Media Exposure Pro Social

RINV : Religious Involvement

INTG : Integrity

CPER : Corruption Perception

CACC: Corruption Acceptability

MAT : Materialism

Construct validity is carried out by ensuring that the research indicators used reach convergent and discriminant validity. Exploratory factor analysis (EFA) was used to assess convergent validity (Hill \& Hughes, 2007). Table 2 shows the EFA result, and the sufficiency and fitness of the sample were identified by KMO measure $(\mathrm{KMO}=.794)$ and Bartlett's test of sphericity $\left(\chi^{2}(296)=2912,375, \mathrm{p}=\right.$ o.ooo).

Table 2. Exploratory Factor Analysis

\begin{tabular}{|c|c|c|c|c|c|c|c|}
\hline & 1 & 2 & 3 & 4 & 5 & 6 & 7 \\
\hline MEAS 1 & & & & & & & 0.797 \\
\hline MEAS2 & & & & & & & 0.830 \\
\hline $\mathrm{MEAS}_{3}$ & & & & & & & 0.773 \\
\hline MEPS 1 & & & & & & 0.663 & \\
\hline MEPS 2 & & & & & & 0.784 & \\
\hline $\mathrm{MEPS}_{3}$ & & & & & & 0.775 & \\
\hline RINV1 & & & 0.765 & & & & \\
\hline $\mathrm{RINV}_{2}$ & & & 0.825 & & & & \\
\hline $\mathrm{RINV}_{3}$ & & & 0.853 & & & & \\
\hline $\mathrm{RINV}_{4}$ & & & 0.728 & & & & \\
\hline INTGı & & & & & 0.876 & & \\
\hline INTG2 & & & & & 0.854 & & \\
\hline $\mathrm{INTG}_{3}$ & & & & & 0.749 & & \\
\hline MAT1 & & & & 0.829 & & & \\
\hline MAT2 & & & & 0.885 & & & \\
\hline $\mathrm{MAT}_{3}$ & & & & 0.868 & & & \\
\hline CPER 1 & 0.861 & & & & & & \\
\hline CPER2 & 0.913 & & & & & & \\
\hline $\mathrm{CPER}_{3}$ & 0.891 & & & & & & \\
\hline CPER4 & 0.891 & & & & & & \\
\hline $\mathrm{CACC}_{1}$ & & 0.839 & & & & & \\
\hline $\mathrm{CACC}_{2}$ & & 0.818 & & & & & \\
\hline $\mathrm{CACC}_{3}$ & & 0.819 & & & & & \\
\hline $\mathrm{CACC}_{4}$ & & 0.748 & & & & & \\
\hline
\end{tabular}

Extraction Method: Principal Component Analysis; Rotation Method: Varimax with Kaiser Normalization;

a. Rotation converged in 6 iterations. 
To confirm the EFA results, a confirmatory factor analysis (CFA) was performed to assess the overall goodness-of-fit of all the constructs to determine the validity of the. Table 4 shows the model statistics for the measurement model (CFA). The results showed that the convergent validity of the research items was supported $\left(\chi^{2}=365,251 ; \mathrm{df}=231 ; \chi^{2} / \mathrm{df}=1,581 ; \mathrm{TLI}=0.942 ; \mathrm{CFI}=0.952 ; \mathrm{RMSEA}=0.049\right)$.

Table 4: Model fit statistics for measurement model

\begin{tabular}{|c|c|c|}
\hline Item & Standardized Regression Weight & Critical Ratio \\
\hline MEAS1 & 0,671 & \\
\hline MEAS2 & 0,837 & 0,827 \\
\hline $\mathrm{MEAS}_{3}$ & 0,633 & 8,033 \\
\hline MEPS1 & 0,679 & \\
\hline MEPS $2_{2}$ & 0,783 & 8,105 \\
\hline $\mathrm{MEPS}_{3}$ & 0,666 & 8,343 \\
\hline RINV1 & 0,773 & \\
\hline $\mathrm{RINV}_{2}$ & 0,843 & 12,761 \\
\hline $\mathrm{RINV}_{3}$ & 0,780 & 11,988 \\
\hline $\mathrm{RINV}_{4}$ & 0,619 & 9,377 \\
\hline INTG1 & 0,776 & \\
\hline INTG2 & 0,803 & 9,896 \\
\hline $\mathrm{INTG}_{3}$ & 0,671 & 9,271 \\
\hline MAT1 & 0,827 & \\
\hline MAT2 & 0,871 & 15,226 \\
\hline $\mathrm{MAT}_{3}$ & 0,845 & 14,839 \\
\hline CPER1 & 0,814 & \\
\hline CPER2 & 0,903 & 17,052 \\
\hline $\mathrm{CPER}_{3}$ & 0,888 & 16,657 \\
\hline $\mathrm{CPER}_{4}$ & 0,848 & 15,588 \\
\hline $\mathrm{CACC}_{1}$ & 0,799 & \\
\hline $\mathrm{CACC}_{2}$ & 0,827 & 13,158 \\
\hline $\mathrm{CACC}_{3}$ & 0,762 & 12,143 \\
\hline $\mathrm{CACC}_{4}$ & 0,697 & 10,987 \\
\hline
\end{tabular}

Discriminant validity was determined by assessing the square root of the AVE value of each construct greater than the correlation value between dimensions (Fornell \& Larcker, 1981). Tables 5 show the assessment of discriminant validity was achieved.

Table 5: Discriminant Validity

\begin{tabular}{|l|c|c|c|c|c|c|c|}
\hline & MEAS & MEPS & RINV & INTG & CPER & CACC & MAT \\
\hline MEAS & $\mathbf{0 . 7 1 9}$ & & & & & & \\
\hline MEPS & $0.348^{* *}$ & $\boldsymbol{0 . 7 1 1}$ & & & & & \\
\hline RINV & $0.321^{* *}$ & $-0.321^{* *}$ & $\boldsymbol{0 . 7 5 8}$ & & & & \\
\hline INTG & -0.065 & -0.015 & 0.022 & 0.752 & & & \\
\hline CPER & -0.115 & -0.077 & -0.138 & 0.022 & 0.863 & & \\
\hline CACC & $-0.200^{*}$ & $-0.200^{* *}$ & $-0.385^{* *}$ & 0.197 & $0.197^{* *}$ & $\boldsymbol{0 . 7 7 2}$ & \\
\hline MAT & $-0.132^{*}$ & $-0.229^{* *}$ & $-0.214^{* *}$ & $0.288^{* *}$ & $0.277^{* *}$ & $0.368^{* *}$ & $\boldsymbol{o . 8 4 7}$ \\
\hline
\end{tabular}

${ }^{* *}$ Correlation is significant at the 0.01 level (2-tailed); Values in the diagonal (bolded and italics) are the square roots of AVE.

Table 6 shows the results of hypothesis testing. The results show that 4 of the 8 hypotheses are supported. The goodness-of-fit results are as follows: $\chi^{2}=333,405 ; \mathrm{df}=237 ; \chi^{2} / \mathrm{df}=1.407 ; \mathrm{TLI}=0.960$; 
$\mathrm{CFI}=0.965 ;$ RMSEA $=0.041$

Table 6: Hypotheses Testing (Structural Model)

\begin{tabular}{|l|l|c|c|c|l|}
\hline Hypothesis & Path & Standardized Regression Weight & Standard Error & Critical Ratio & Result \\
\hline $\mathrm{H}_{1}$ & MEAS $\rightarrow$ MAT & $-0,153$ & 0,096 & $-2,081$ & Supported \\
\hline $\mathrm{H}_{2}$ & MAT $\rightarrow$ CACC & $\mathbf{0 , 2 8 2}$ & 0,054 & 3,755 & Supported \\
\hline $\mathrm{H}_{3}$ & MEAS $\rightarrow$ CPER & $-0,105$ & 0,097 & $-1,441$ & Not supported \\
\hline $\mathrm{H}_{4}$ & CPER $\rightarrow$ CACC & 0,089 & 0,048 & 1,322 & Not supported \\
\hline $\mathrm{H}_{5}$ & MEPS $\rightarrow$ INTG & 0,040 & 0,088 & 0,503 & Not supported \\
\hline $\mathrm{H} 6$ & INTG $\rightarrow$ CACC & 0,046 & 0,064 & 0,628 & Not supported \\
\hline $\mathrm{H}_{7}$ & MEPS $\rightarrow$ RINV & 0,405 & 0,071 & 4,793 & Supported \\
\hline $\mathrm{H} 8$ & RINV $\rightarrow$ CACC & $-0,344$ & 0,083 & $-4,787$ & Supported \\
\hline
\end{tabular}

\section{Discussion}

No country is completely free from corruption. Corruption does not only occur in middle- and lowincome countries. In a high-income country like America, corruption is also serious problem. Many research models have been developed and theories are used to understand corruption. As corruption is something complex, a multi-disciplinary approach and multiple perspectives can be used to understand corruption later. This study uses a stimulus-organism-response framework. The results showed that anti-social media exposure had a relationship with materialism. Furthermore, materialism has a positive relationship with acceptance of corruption. The results of this study indicate that anti-social media exposure has a negative relationship with materialism $\left(\mathrm{H}_{1}\right)$. This means that the higher the exposure to anti-social media (such as news about theft, fights, and other negative things), the lower the value of individual materialism. It can be understood that the media's exposure to these negative things can give a sense of worry that these negative things could happen to him (experiencing theft, destruction) of the material/property he owns). However, his enjoyment of materiality influences the individual in his acceptance of corruption ( $\mathrm{Hz}$ ). Thus, from the results of this study, it can be said that individuals who like to buy and own a lot of goods and like luxury tend to accept corruption because corruption is one of the ways to obtain these goods and luxuries.

The results also show that exposure to anti-social media does not have a significant relationship with perceptions of corruption. Likewise, perceptions of corruption do not have a significant relationship with acceptance of corruption. This can be understood as follows. The indicator used to measure anti-social media exposure in this study relates to media exposure that broadcast anti-social issues such as shootings, fights, theft, and so on. The anti-social exposures mentioned do not have a direct connection with perceptions of corruption. On the other hand, corruption is related to money. In this research, anti-social media exposure does not emphasize money as anti-social. Thus, this study then shows an insignificant relationship between exposure to anti-social media and perceptions of corruption $\left(\mathrm{H}_{3}\right)$. The results of this study also show that perceptions of corruption do not have a significant relationship with acceptance of corruption $\left(\mathrm{H}_{4}\right)$. That in the perception of individuals there are people associated with the public who often commit corruption, it will not then be related that these individuals will also be able to accept corruption. Even though $\mathrm{H}_{3}$ and $\mathrm{H}_{4}$ are not supported in this study, they provide a positive insight that even if individuals have the perception that public employees often commit corruption, it will not lead the individual to accept corruption as acceptable behaviour.

The results showed that pro social media exposure did not have a significant relationship with individual integrity $\left(\mathrm{H}_{5}\right)$. This can be explained as follows. Integrity is the conformity between what is said and what is done. A person with integrity will be consistent with his values. Integrity is associated with positive things such as trust, fairness, and honesty. Integrity is influenced by many factors, including environmental and internal factors of the individual. The insignificance of the 
results of this study could be because the research respondents were young people. Research conducted by Sihombing (2018) shows that Indonesian youths do not understand what integrity means. They can show the characteristics of integrity, but it is not easy for them to explain what integrity is. The inability to explain but recognize integrity behaviour has also been demonstrated through the Youth Integrity Survey in Indonesia (Transparency International, 2013). The lack of understanding of integrity among young people can be caused by a lack of media exposure to integrity itself. Many and almost every day the Indonesian media provide news about corruption, where many of the perpetrators are government officials. The lack of role models from Indonesian leaders regarding integrity can make it difficult for young Indonesians to understand integrity.

Individual integrity does not have a significant relationship with acceptance of corruption (H6). The results of this study provide provocative finding where individual integrity does not have a significant relationship with corruption acceptability. Further research needs to be done in this regard considering that integrity and corruption are often linked to the understanding that individuals with integrity are guaranteed not to commit corruption. It can be stated that corrupt behaviour is often associated with the person's low integrity. However, the results of this study do not show a significant relationship between integrity and acceptance of corruption. The results of this study contradict the theory because the samples used in this study were youth. Young people are characterized as individuals who want to be instantaneous, not often exposed to matters related to integrity. Research conducted by Purnomo (2020) on the corruption and integrity of youth in Indonesia shows that young people tend to be more permissive to actions that are not have integrity. In the study, young people were asked how much far they can accept a certain violation of ethical values, for example: giving additional money to officers so they can good health service. The results of these studies indicate that when the integrity value is in a grey area, then there is the tendency of individuals to be permissive in responding to a circumstance. Even in that study, young people supported integrity, but in practice often these values clash with interests or needs others, causing people to be permissive to the rules. Specifically, that permissiveness arises when it comes to breaking the law for the sake of help his family.

The results of the analysis show that pro social media exposure has a significant relationship with religious involvement $\left(\mathrm{H}_{7}\right)$. Young people in Indonesia have experienced an increasing trend in their understanding of religion. This increase can be seen for example the high interest in understanding religion through the internet and social media (PPIM, 2021; Hatta, 2018). Specifically, the internet and social media have encouraged and created new public spaces on religion that can be accessed by anyone, including young people. It can be stated that social media and the internet have become sources of religious information and have either intentionally or unintentionally exposed this information to young people. Furthermore, a study in 2020 showed that 58 percent of young people in Indonesia prefer to study religion through social media such as YouTube or Instagram (Soraya, 2020). Furthermore, the results of the study also show that religious involvement has a negative relationship with acceptance of corruption (H8). In other words, the higher the involvement of religion, the lower the acceptance of corruption. As stated earlier that Indonesian youth are more involved in religious activities, their interest in religion makes them understand negative things such as corruption which should be avoided by young people.

\section{Conclusion}

The aim of this study is to predict acceptance of corruption using a stimulus-organism-response framework. The results of the analysis show that there are four supported hypotheses, namely those related to the relationship between exposure to anti-social media and materialism, the connection between materialism and acceptance of corruption, the relationship between pro-social media exposure and religious involvement, and religious involvement with acceptance of corruption. It can be concluded that the variables that are important in understanding the acceptability of corruption among Indonesian youth are materialism and religious involvement. 
This study cannot be separated from the limitations of the study. Specifically, this study used a judgmental sampling design in which the respondents of the study were focused on young people. Although the use of this sampling design is in accordance with the research objectives, the results of the study are not intended to be generalized to other young people in the same or different contexts. Then, this study is a cross-sectional study which only describes a situation or condition at a certain time. Thus, this study does not intend to prove a causal relationship in explaining the phenomenon under study. In connection with research that can be carried out in the future, further research can test this model by using youth respondents in different areas. Then, further research can add other variables that reflect the stimulus, for example the environment, peers, and others.

\section{References}

Abashidze, A. \& Gvalia, G. (2020). A cost-benefit analysis of border corruption in the conflict regions in Georgia and Moldova. European Scientific Journal, 16(1), 46-72.

Abbas, D., Ali, M., Nohong, M. \& Sobarsyah, M. (2020). Predicting the Financial Behavior of the Religious Organization Board in Indonesia. Journal of Asian Finance, Economics and Business, 7(12), 1159-1166. https://doi.org/10.13106/JAFEB.2020.VOL7.N10.339

Abdullahi, A. A., \& Abdulquadri, N. T. (2018). New media and adolescents' sexual behaviour in sub-sahara Africa: linking theories to realities. SAGE Open. http://doi.org/10.1177/2158244018804606

Aliyu, M., Yusuf, S.N. \& Salisu, K.I. (2018). CORRUPTION and materialism: a bane for good governance and development in Nigeria. Nigerian Journal of Social Studies, XXI (1), 239-257.

Angwarmase, E., Candrawati, E. \& Warsono (2016). Paparan media berhubungan perilaku seksual pada remaja. Nursing News, 1(2), 210-222.

Ameri, Z., Mirzakhani, F., Nabipour, A. R., Khanjani, N., \& Sullman, M. (2017). The relationship between religion and risky behaviors among Iranian University Students. Journal of religion and health, 56(6), 2010-2022. https://doi.org/10.1007/s10943-016-0337-1

Arshad, A., Zafar, M., Fatima, I. \& Khan, S.K. (2015). The Impact of perceived risk on online buying behaviour. International Journal of New Technology and Research, 1(8), 13-18.

Audi, R., \& Murphy, P. (2006). The many faces of integrity. Business Ethics Quarterly, 16(1), 3-21.

Bai B., Liu X. \& Kou, Y. (2014). Belief in a just world lowers perceived intention of corruption: the mediating role of perceived punishment. PLOS ONE, 9(5): e97075. http://doi.org/10.1371/journal.pone.0097075

Barnard, A., Schurink, W. \& De Beer, M. (2008). A conceptual framework of integrity. SA Journal of Industrial Psychology, 34(2), 40-49.

Behal, M., \& Soni, P. (2018). Media Use and Materialism: A Comparative Study of Impact of Television Exposure and Internet Indulgence on Young Adults. Management and Labour Studies, 43(4), 247-262. https://doi.org/10.1177/0258042X18791613

Bowen, N.K. \& Guo, S. (2012). Structural Equation Modelling. NY: Oxford University Press, Inc.

Burroughs, J., \& Rindfleisch, A. (2002). Materialism and well-being: A conflicting values perspective. Journal of Consumer Research, 29(3), 348-370. doi:10.1086/344429

Carbajal, C. \& Chavez, E. (2007). Trustworthiness and integrity: cardinal virtues for engineers. Latin American and Carribean Journal of Engineering, 1(1), 8-11.

Cheng, C., Jiang, D., Cheng, B., Riley, J.H., \& Jen, C. (2015). When do subordinates commit to their supervisors? different effects of perceived supervisor integrity and support on Chinese and American employees. Leadership Quarterly, 26(1), 81-97.

Civelek, M.E. (2018). Essentials of Structural Equation Modeling. Zea E-Books. 64. https://digitalcommons.unl.edu /zeabook/64

CNN Indonesia (2020). Satu tahun Corona di Indonesia: Korupsi Tak Berhenti di Masa Pandemi. Retrieved from https://www.cnnindonesia.com/nasional/20210302092301-20-612489/korupsi-tak-berhenti-di-masa-pandemi

Colquitt, J.A., Scott, B.A. \& LePine, J.A. (2007). Trust, trustworthiness, and trust propensity: a meta-analytic test of their unique relationship with risk taking and job performance. Journal of Applied Psychology, 92(4), 909927.

Cuervo-Cazurra, A. (2016). Corruption in international business. Journal of World Business, 51(1), 35-49 den Hamer. A.H., Konijn, E.A., Plaisier, X.S., Keijer, M.G., Krabbendam, L.C. \& Bushman, B.J. (2017). The content-based media exposure scale (C-ME): Development and validation. Computers in Human Behaviour, 72, 549-557. http://dx.doi.org/10.1016/j.chb.2017.02.050 
Dimant, E. \& Tosato, G. (2017). Causes and effects of corruption:what has past decade's empirical research taught us? A Survey. Journal of Economic Surveys. oo(o), 1-22.

Dobel, J. P. (2016). Integrity and corruption. Springer International Publishing Switzerland 2016 Ali Farazmand Global Encyclopedia of Public Administration, Public Policy, and Governance 10.1007/978-3-319-31816-5_2824-1.

Ebrahimi, E., Sadeghuaziri, F. \& Abyaneh, S.S. (2020). The dark-side of consumer-brand relationship: do ideal selfcongruence, brand attachment and personality factors affect negative consumer behaviour? Iranian Journal of Management Studies, 13(2), 289-315.

Fadhil, H. (2018). KPK: Banyak pejabat korupsi, kadang yang ketangkap itu sial. Retrieved Desember 30, 2020, from https://news.detik.com/berita/d-4319175/kpk-banyak-pejabat-korupsi-kadang-yang-ketangkap-itukarena-sial

Farhanfar, M., Nadi, M. \& Molavi, H. (2015). The relationship between religious commitment, religious involvement, and empathy with aggression among high school students. Research in Cognitive and Behavioral Sciences, 5(1(8)), 67-79. https://www.sid.ir/en/journal/viewpaper.aspx?id=574192

Ferguson, M.J. \& Bargh, J.A. (2004). How social perception can automatically influence behavior. Trends in Cognitive Sciences, 8(1), 33-39. https://doi.org/10.1016/j.tics.2003.11.004

Fornell, C., \& Larcker, D. (1981). Evaluating structural equation models with unobservable variables and measurement error. Journal of Marketing Research, 18(1), 39-50. doi:10.2307/3151312

French, D.C., Eisenberg, N., Vaughan, I., Purwono, U. \& Suryanti, T.A. (2008). Religious involvement and the social competence and adjustment of Indonesia muslim adolescent of Indonesia muslim adolescent. Developmental Psychology, 44(2) 597-611.

Geusens, F., Bigman-Galimore, C. A., \& Beullens, K. (2020). A cross-cultural comparison of the processes underlying the associations between sharing of and exposure to alcohol references and drinking intentions. New Media \& Society, 22(1), 49-69. http://doi.org/10.1177/1461444819860057

Golmohammadian, M. , Nasab, M.B., Nejad, P.Y., Nourisamarin, S. \& Moyedfar, H. (2014). The relationship between religious orientation and job involvement in faculty members. Global Advanced Research Journal of Management and Business Studies, 3(12), 542-547.

Graham, C. \& Vicheth, C.S. (2015). Questioning corruption: A national survey on youth perceptions of corruption and integrity in Cambodia. Cambodia: Transparency International.

Hair, J. F., Black, W. C., Babin, B. J., \& Anderson, R. E. (2019). Multivariate Data Analysis (8th ed.). United Kingdom: Cengage Learning.

Hanna, N. \& Wozniak, R.S. (2001). Consumer Behavior: An Applied Approach. NJ: Prentice Hall.

Hanoteau, J., \& Vial, V. (2014). Grease or sand the wheel? The effect of individual bribes on the drivers of aggregate productivity growth. Journal of Indonesian Economy and Business: JIEB., 29(1), 1-16,93-94. Retrieved from https://e-resources.perpusnas.go.id:2350/scholarly-journals/grease-sand-wheel-effect-individual-bribeson/docview/1658398246/se-2?accountid=25704

Hatta, M. (2018). Media sosial sebagai sumber keberagamaan alternatif remaja dalam fenomena cyber religion. Jurnal Kajian Dakwah dan Kemasyarakatan, 22(1), 2018, 1-30.

Heissner, S. (2015). Managing business integrity: Prevent, detect, and investigate white-collar crime and corruption. Switzerland: Springer International Publishing.

Heo, Y., Hou, F. \& Park, S.G. (2020). Does corruption grease or sand the wheels of investment or innovation? Different effects in advanced and emerging economies. Applied Economics, 53(1), 35-6o.

Hill, C.R., \& Hughes, J.N. (2007). An examination of the convergent and discriminant validity of the strengths and difficulties questionnaire. Sch Psychol Q, 22(3), 380-406. doi: 10.1037/1045-3830.22.3.380

Hill, P. C., Pargament, K.I., Hood, R.W. Jr., Mccullough, M.E., Swyers, J.P., Larson, D.B. \& Zinnbauer, B.J. (20oo). Conceptualizing religion and spirituality: points of commonality, points of departure. Journal for The Theory of Social Behaviour, 30, 51-77.

Hoinaru, R., Buda, D., Borlea, S.N., Văidean, V.L. \& Achim, M.V. (2020). The impact of corruption and shadow economy on the economic and sustainable development. Do they "sand the wheels" or "grease the wheels"? Sustainability. 12(2):481. http://doi.org/10.3390/su12020481

Huang, Q. (2020). How does news media exposure amplifypublics' perceived health risks about air pollution in China?A conditional media effect approach. International Journal of Communication, 4, 1705-1724.

Huberts, L.W.J.C. (2018) Integrity: what it is and why it is important, Public Integrity, 20:sup1, S18-S32, DOI: 10.1080/10999922.2018.1477404

Jacoby, J. (2002). Stimulus-Organism-Response reconsidered: An evolutionary step in modeling (consumer) behavior. Journal of Consumer Psychology, 12(1), 51-57.

Jancsics, D. (2014). Interdisciplinary perspectives on corruption. Sociology Compass, 8(4), 358-372. 
Jones, J.R. (2017). Media and Social Media's Impact on Citizens' Perception of the Frequency of Crime Occurrence in the United States. American International Journal of Social Science, 6(3), 97-102.

Kamil, I. (2021). Bupati bandung barat Aa Umbara jadi tersangka KPK, ini paparan harta kekayaannya. Retrieved from https://nasional.kompas.com/read/2021/04/o2/o6412651/bupati-bandung-barat-aa-umbara-jaditersangka-kpk-ini-paparan-harta.

Karthikevan, C. (2017). A meta-analytical study on leadership integrity : A leadership ethics perspective. International Journal of Management, IT E Engineering, 7(4), 240-263.

Kepplinger, H.M. (2017). Reciprocal effects: toward a theory of mass media effects on decision makers. Press/Politics, 12(2), 3-23.DOI: 10.1177/1081180Xo7299798

Kline, R. B. (2005). Principles and practice of structural equation modeling (2nd ed.). New York, NY: Guilford.

Knotts, T.L. (200o). Religious involvement and dispositional characteristics as predictors of work attitudes and behavior. Dissertation. 155. https://digitalcommons.latech.edu/dissertations/155

Leister, D., \& MacLachlan, D. (1975). Organizational self-perception and environmental image measurement. The Academy of Management Journal, 18(2), 205-357.

Li, X. (2018). Media exposure, perceived efficacy, and protective behaviours in a public health emergency. International Journal of Communication, 12, 2641-266o.

Liang, Y., Liu, L., Tan X, Huang, Z, Dang, J. \& Zheng, W. (2016)The effect of self-esteem on corrupt intention: The mediating role of materialism. Frontiers in Psychology, 7:1063. doi: 10.3389/fpsyg.2016.010633

Linstead, S. Marechal, G. \& Griffin, R.W. (2014). Theorizing and researching the dark side of organization. Organization Studies, 35(2), 165-188.

Locatelli, G., Mariani, G., Sainati, T. \& Greco, M. (2017). Corruption in public projects and mega projects: There is an elephant in the room! International Journal of Project Management, 35, 252-268.

Makhlouf, H.H. (2016). Corruption in the international business environment. The Journal of Human Resource and Adult Learning, 12(1), 32-39.

Masood, A., Musarrat, R. \& Mazahir, R. (2016). Increased Materialistic Trends among Youth. Journal of Educational, Health and Community Psychology, 5(3), 56-77.

McKenzie, M., Modeste, N., Marshak, H., \& Wilson, C. (2015). Religious Involvement and Health-Related Behaviors Among Black Seventh Day Adventists in Canada. Health Promotion Practice, 16(2), 264-270.

Merhi, M.I. \& Ahluwalia, P. (2018). Digitas Economy and Corruption Perceptions: A Cross-Country Analysis. The International Journal of Digital Accounting Research, 8, 29-47.

Moorman, R.H. \& Grover, S. (2009). Does leader integrity matter to followers? an uncertainty management-based explanation. International Journal of Leadership Studies, 5(2), 102-114.

Mothersbaugh, D.L. \& Hawkins, D.I. (2016). Consumer Behaviour: Building Marketing Strategy. NY: McGrawHillEducation.

Mueller, P.S., Plevak, D.J. \& Rummans, T.A. (2001). Religious involvement, spirituality, and medicine: implications for clinical practice. Mayo Clin Proc., 76(12):1225-35. doi: 10.4065/76.12.1225. PMID: 11761504.

Neve, M. \& Trivedi, R. (2020). Materialism and Media Usage: To study the role of media in increasing materialism among youths with special reference to social media exposure. International Journal of Advanced Science and Technology, 29(8s), 2431-2436.

Nur-tegin, K. \& Jakee, K. (2020). Does corruption grease or sand the wheels of development? New results based on disaggregrated data. The Quarterly Review of Economics and Finance, 75, 19-30.

Ones, D.S., Viswesvaran, C. \& Schmidt, F.L. (1993). Comprehensive meta-analysis of intengrity test validities and implications for personnel selection and theories of job performance. Journal of Applied Psychology, 78, 679703.

Pinto, M. R., Mota, A.O., Leite, R.S. \& Alves, R.C. (2017). Investigating the influencers of materialism in adolescence. Tourism \& Management Studies, 13(1), 66-74. DOI: 10.18089/tms.2017.13109

PPIM (2021). Tren keberagaman gerakan hijrah kontemporer. Jakarta: Universitas Islam Negeri Jakarta. Retrieved from https://ppim.uinjkt.ac.id/wp-content/uploads/2021/o2/RINGKASAN-EKSEKUTIF_fixed-30o121-2.pdf.

Prottas, D.J. \& Nummelin, M.R. (2018). Behavioral integrity, engagement, organizational citizenship behavior, and service quality in a healthcare setting. Journal of Healthcare Management, 63(6), 410-424, https://pubmed.ncbi.nlm.nih.gov/30418370/

Putri, D.A. \& Nihayah, Z. (2017). The effect of moral integrity, lifestyle, and organizational culture on anticorruption intention. TAZKIYA Journal of Psychology, 5(2), 289-30o.

Pyman, M., Scott, D., Waldron, A., \& Voika, I. (2008). Building integrity and reducing corruption risk in defence establishments. Connections, $7(2), 21-44$.

Richins, M.L. (2004). The material values scale: measurement properties and development of a short form. Journal of Consumer Research, 31(1), 209-219, http://doi.org/10.1086/383436 
Rizzica, L. \& Tonello, M. (2015). Exposure to media and corruption perceptions. Working Paper No. 1043, Italy: Bank of Italy

Roth, D.L., Mwase, I., Holt, C.L., Clark, E.M., Lukwago, S.N. \& Kreuter, M.W. (2012). Religious involvement measurement model in a national sample of African Americans. J Relig Health, 51(2), 567-578. http://doi:10.1007/s10943-011-9475-7

Saithibvongsa, P. \& JinKyo, S. (2019). Individual perceived corruption diminishes the work effectiveness and organizational performance: Public organizations in Laos. International Journal of Economics and Management, 1(1), $26-46$.

Salvatore, C. \& Rubin, G. (2018). The influence of religion on the criminal behavior of emerging adults. Religions, 9(5):141. https://doi.org/10.3390/rel9050141

Schiffman, L. G., \& Wisenblit, J. (2015). Consumer Behaviour, ed.11., UK: Pearson Education Limited.

Sihombing, S.O. (2018). Youth perceptions toward corruption and integrity: Indonesian context. Kasetsart Journal of Social Sciences, 39(2), 299-304, https://doi.org/10.1016/j.kjss.2018.03.004.

Simmonds, D.M., Guha, S. \& McGowan, C.B. (2016). Corruption as an agency problem - currency hedging in corrupt countries. Accounting and Finance Research, 5(1), 38-49.

Skoric, M. M., Zhu, Q., Goh, D., \& Pang, N. (2016). Social media and citizen engagement: A meta-analytic review. New Media \& Society, 18(9), 1817-1839. http://doi.org/10.1177/1461444815616221

Soraya, D.A. (2020). Riset: 58 persen milenial belajar agama di medsos. Retrieved from: https://www.republika.co.id/berita/ql9jmz430/riset-58-persen-milenial-belajar-agama-di-medsos

Sousa, A., Nobre, H., \& Farhangmehr, M. (2019). Cosmopolitanism and the mediating effect of country image on consumers' purchase, visit and investment intentions. The Journal of Asian Finance, Economics and Business, 6(4), 159-170. https://doi.org/10.13106/JAFEB.2019.VOL6.NO4.159

Stainback, K., Hearne, B.N. \& Trieu, M.M. (2020). Covid-19 and the 24/7 news cycle: Does Covid-19 news exposure affect mental health? Socious: Sociological Research for Dynamic World, 6, 1-15.

Syah, A.M. (2020). Pengaruh dakwah media sosial YouTube terhadap religiusitas remaja di MA. Al-Muhtadi Sendangagung. Jurnal Komunikasi dan Penyiaran Islam, 1(2), 20-36.

Tatarko, A. \& Mironova, A. (2016). Values and attitudes towards corruption: A cross-cultural study in four European countries. Working Papers Series: Psychology, WP BRP 61/PSY/201. National Research University Higher School of Economics.

Tempo.co (2021). Nurdin Abdullah peraih tokoh anti korupsi bung hatta award yang ditangkap KPK. Retrieved from http://nasional.tempo.co/read/1437402/nurdin-abdullah-peraih-tokoh-anti-korupsi-bung-hattaaward-yang-ditangkap-kpk/full\&view=ok

Thomas, B.J. (2019) Integrity according to whom? An experiment of the effects of gender, moral integrity, and behavioral consistency on evaluations of leaders. Organization Management Journal, 16(3), 193-207, DOI: $10.1080 / 15416518.2019 .1628698$

Transparency International Indonesia. (2013).Survey integritas anak muda 2012. Retrieved from http://riset.ti.or.id/wp-content/uploads/2018/10/survei_integritas_anak_muda_newsletter_1.pdf.

Transparency International Indonesia. (2021). Indeks persepsi korupsi 2020: korupsi, respons Covid-19 dan kemunduran demokrasi. Retrieved from https://ti.or.id/indeks-persepsi-korupsi-202o-korupsi-responscovid-19-dan-kemunduran-demokrasi/

Tugtekin, E. B., \& Koc, M. (2020). Understanding the relationship between new media literacy, communication skills, and democratic tendency: Model development and testing. New Media E Society, 22(10), $1922-1941$. http://doi.org/10.1177/1461444819887705

Tuhin, M.K.W. (2019). Darkside of consumer behaviour: brand hate and anti-brand actions. The Jahangirnagar Journal of Business Studies, 81(1), 43-54.

Tverdova, Y. (2011). See No Evil: Heterogeneity in public perceptions of corruption. Canadian Journal of Political Science / Revue Canadienne De Science Politique, 44(1), 1-25.

Wee, C.S., Ariff, M.S., Zakuan, N., Ismail, K. \& Ishak, N. (2014). Consumer's perception, purchase intention and actual purchase behavior of organic food products. Review of Integrative Business E Economics Research, 3(2), 378-397.

Wu, X. \& Li, X. (2017). Effects of mass media exposure and social network site involvement on risk perception of and precautionary behaviour toward the haze issue in China. International Journal of Communication, 11, 3975-3997.

Zhang, X., Liang, L., Tian, G., \& Tian, Y. (2020). Heroes or villains? The dark side of charismatic leadership and unethical pro-organizational behavior. International Journal of Environmental Research and Public Health, 17(15), 5546. MDPI AG. http://dx.doi.org/10.339o/ijerph17155546

Zimelis, A. (2020). Corruption research: a need for integrated approach. International Area Studies Review, 23(3), $288-306$. 


\section{Appendix 1: List of Indonesian government officials and their cases}

\begin{tabular}{|c|c|c|}
\hline Name & Position & Case \\
\hline Ismunandar & East Kutai Regent & Bribery case related to infrastructure work in East Kutai Regency in 2019-2020. \\
\hline $\begin{array}{l}\text { Encek Unguria } \\
\text { (Ismunandar's wife) }\end{array}$ & $\begin{array}{l}\text { Chairman of the East Kutai Regional } \\
\text { People's Representative Council (DPRD) }\end{array}$ & Bribery case related to infrastructure work in East Kutai Regency in 2019-2020. \\
\hline Edhy Prabowo & $\begin{array}{l}\text { Minister of Maritime Affairs and } \\
\text { Fisheries }\end{array}$ & $\begin{array}{l}\text { Bribery case for permits for ponds, businesses and / or management of fisheries or } \\
\text { other similar marine commodities in } 2020 \text {. }\end{array}$ \\
\hline $\begin{array}{l}\text { Ajay Muhammad } \\
\text { Priatna }\end{array}$ & Mayor of Cimahi & Bribery case related to a permit to build a hospital in Cimahi- West Java in 2020. \\
\hline Wenny Bukamo & $\begin{array}{l}\text { Regent of Banggai Laut - Central } \\
\text { Sulawesi }\end{array}$ & Bribery cases in the 2020 Regional Head Election. \\
\hline Aa Umbara & Regent of Bandung Barat - West Java & $\begin{array}{l}\text { A case of bribery in the procurement of emergency response goods for the Covid-19 } \\
\text { pandemic at the Social Service for the Regional Government of West Bandung } \\
\text { Regency in 2020. }\end{array}$ \\
\hline Juliari Batubara & Social Minister & $\begin{array}{l}\text { A bribery related to the appointment of a groceries procurement partner for } \\
\text { residents affected by Covid-19. }\end{array}$ \\
\hline Nurdin Abdullah & Governor of South Sulawesi & $\begin{array}{l}\text { A bribery case related to an infrastructure work project in Sinjai Regency, South } \\
\text { Sulawesi }\end{array}$ \\
\hline Azis Samsudin & $\begin{array}{l}\text { Deputy chairman of the People's } \\
\text { Representative Council }\end{array}$ & Several cases of bribery related to the handling of corruption cases \\
\hline
\end{tabular}

\section{Source: www.cnnindonesia.com (2021) and Kamil (2021)}

\section{Appendix 2:}

\begin{tabular}{|c|c|c|}
\hline Code & Item & Source \\
\hline $\begin{array}{l}\mathrm{CACC}_{1} \\
\mathrm{CACC}_{2} \\
\mathrm{CACC}_{3} \\
\mathrm{CACC}_{4}\end{array}$ & $\begin{array}{l}\text { I can accept if a parent gives money to the Director of a prestigious school so that his son can be accepted into the } \\
\text { school without exams. } \\
\text { I can accept if a driver who has committed a serious traffic violation offers money to the police to avoid a fine. } \\
\text { I can accept if a department official accepts someone from family or friends, and not another candidate with higher } \\
\text { qualifications. } \\
\text { It usually takes between } 3 \text { and } 6 \text { months to issue a building permit. I can accept if an entrepreneur offers money to } \\
\text { a public official to get a building permit in less than } 2 \text { weeks. }\end{array}$ & $\begin{array}{l}\text { Tatarko and Mironova } \\
(2016)\end{array}$ \\
\hline \begin{tabular}{l|} 
INTG1 \\
INTG2 \\
INTG3
\end{tabular} & $\begin{array}{l}\text { People with integrity are people who never lie or cheat. } \\
\text { People with integrity never break the law under any circumstances. } \\
\text { People with integrity are never involved in corruption (such as accepting or giving bribes) under any circumstances. }\end{array}$ & $\begin{array}{l}\text { Graham and Vicheth } \\
(2015)\end{array}$ \\
\hline \begin{tabular}{l|} 
RINV1 \\
RINV2 \\
RINV $_{3}$ \\
RINV4 $_{4}$ \\
\end{tabular} & $\begin{array}{l}\text { I often realize the presence of God in my life. } \\
\text { I have a personal relationship with God. } \\
\text { When I was sick, I often asked God for healing. } \\
\text { I often pray. }\end{array}$ & Roth et al. (2012) \\
\hline \begin{tabular}{l|} 
CPER 1 \\
CPER $_{2}$ \\
CPER $_{3}$ \\
CPER $_{4}$ \\
\end{tabular} & $\begin{array}{l}\text { Some public servants often use state property for personal gain. } \\
\text { Some public officials still use their positions for personal gain. } \\
\text { Some public officials often expect to be rewarded for providing public services. } \\
\text { Some public officials secretly claim ownership of state-owned property. }\end{array}$ & $\begin{array}{l}\text { Saithibvongsa and } \\
\text { JinKyo (2019) }\end{array}$ \\
\hline \begin{tabular}{l|}
$\mathrm{MAT}_{1}$ \\
$\mathrm{MAT}_{2}$ \\
$\mathrm{MAT}_{3}$
\end{tabular} & $\begin{array}{l}\text { Buying things gives me a lot of fun. } \\
\text { I like a lot of luxury in my life. } \\
\text { I would be happier if I could afford to buy more stuff. }\end{array}$ & Richins (2004) \\
\hline $\begin{array}{l}\mathrm{MEAS}_{1} \\
\mathrm{MEAS}_{2} \\
\mathrm{MEAS}_{3}\end{array}$ & $\begin{array}{l}\text { I often watch on the Internet/TV/games/cell phones about people fighting. } \\
\text { I often watch on the Internet / TV / games / cell phones about people destroying other people's goods/property. } \\
\text { I often watch on the Internet/TV/games/mobile about people who commit corruption. }\end{array}$ & Hamer et al. (2017) \\
\hline \begin{tabular}{l|} 
MEPS $1_{1}$ \\
MEPS $_{2}$ \\
MEPS $_{3}$
\end{tabular} & $\begin{array}{l}\text { I often watch on the Internet/TV/mobile phones about people doing helping others. } \\
\text { I often watch on the Internet/TV/mobile about people standing up for other people. } \\
\text { I often watch the latest news on the Internet/TV/mobile phone. }\end{array}$ & Hamer et al. (2017) \\
\hline
\end{tabular}

